\title{
The Contrastive Analysis of the Speech Act of Invitation Between English and Farsi
}

\author{
Behzad Nazari \\ Islamic Azad University, South Tehran Branch, Tehran, Iran
}

\begin{abstract}
The present paper focuses on the critical properties of sound and artificial invitations in Farsi according to a collected number of impromptu invitations in Farsi. The outcomes were compared and analyzed with the structure of invitations in English. The findings revealed that, in Farsi, the structure of artificial invitations is more intricate than in English. The qualities, based on which we can judge the reality of the invitations, support that in English artificial invitations exist while these qualities are not ample to be relied on in discriminating artificial invitations from sound invitations in Persian. Invitations that follow the factors for being sound invitations in English can be sorted out as ostensible by Persian speakers. The results of this study suggest that a noticeable number of ostensible invitations are applied by Persian speakers in their everyday activities as a superficial politeness indication (ta'arof). The study points out that the cornerstone in using ostensible invitations in Farsi is promoting face for both the speaker and the listener.
\end{abstract}

Keywords: speech act, invitation, ostensible invitation, formal invitation, informal invitation, politeness

\section{Introduction}

Throughout history language has been studied from different aspects. One of the most outstanding aspects of language which Iranian teachers of English are faced with roots at similar and different parameters of English and Persian languages regarding Contrastive Analysis. According to Lado (1957), the more similarities between first language (L1) and second language (L2) the more simplicity, and the more differences between them the more difficulty the learners face in learning the L2. As far as students of language are supposed to learn different functions of language, the present study aims at revealing similar and different areas of one of the functions of language, "invitation", through a variety of examples. These examples are meticulously chosen from different authentic materials of both English and Persian in order to pave the way for the readers to recognize not only the exact equivalence of the examples, but also to perceive the scrupulous situations of their usage.

Searle (1979) defined invitation as a speech act attempted by the speaker to get the hearer to do something. As an illocutionary speech act, invitation entails perlocutionary effect. As the matter of fact, an invitation leads to a cost to the speaker, and a benefit to the addressee. Hancher (1979) claimed that, inviting is a "commisive directive" speech act in that, it not only commits a speaker to some future action, but it also causes the hearer to take a particular action.

Behzad Nazari, instructor, master, English Language Department, Islamic Azad University, South Tehran Branch. 
The present investigator pursued to devise a descriptive framework for the contrastive analysis of the speech act of invitation between English and Persian. The paper covers a collected number of instances extracted from different novels, stories, and other pedagogical books in both verbal and written invitations in English and Farsi.

Unfortunately, many language students find it problematic to make accurate uses of "invitation" as one of the language functions in real life situation due to interlanguage errors.

\section{Instances of Invitation}

In the following instances numbers stand for the new examples, letter "a" stands for the literal English translation, and letter "b" for the exacting English equivalent. In fact, Persian examples are typped in the form of Library Congress (LC) transliteration.

\section{Formal Verbal Persian Invitation}

1. Agar malakeye ǰahan eftexāre yek asrāne be īn deldāde bedan.

a. If queen world honor one afternoon tea to this lover give

$b$. If the world's queen gives this lover the honor of an afternoon tea. (I will be really glad)

2. Myše lotfan šomāro barāye nāhār da'vat konam?

a. May please you for lunch invite I?

b. May I invite you for lunch?

3. āyā mayl dāryd šām rā bā mā boxūryd?

a. Do like you dinner with us eat?

b. Would you like to have dinner with us?

4. Mayl dāry fardā bā man nahār boxūry?

a. Do you like tomorrow with me lunch eat?

$b$. Would you like to have lunch with me tomorrow?

5. Mayl dāry rūze ǰom'eh bā man byāyy kūh navardy?

a. Do you like day Friday with me come to mountain?

b. Would you like to go climbing with me on Friday?

6. Mayl dāry byāyy pyknyk?

a. Do you like come picnic?

b. Would you be interested in coming on a picnic?

7. Mayl dārym šomā va hamsaretān mehmāne mā bāšyd?

a. We like you and your wife our guests be.

$b$. We'd like you and your wife to be our guests.

\section{Informal Verbal Persian Invitation}

8. Byā va memhāne mā bāš; īnjātanhā namān.

a. Come and guest we be; here alone don't stay.

b. Come and be our guest; don't stay alone.

9. Fardā šab bā ham šām boxūrym.

a. Tomorrow night with together dinner eat. 
b. Let's eat dinner together tomorrow night.

10. Byā fardā šab bā ham šām boxūrym.

a. Tomorrow night together dinner eat.

b. Let's eat dinner together tomorrow night.

11. Gorosneat nyst? Myšavad yek ǰāyy hamyn ǰahā tah bandy kard.

a. Hungry you not? Possible a place around these places eat something.

$b$. Aren't you hungry? We can eat something around here.

12. Bā man myāy Dašte Moghān, Nynā?

a. With me do you come Dashte Moghan, Nina?

b. Do you come to Moghan Dasht with me, Nina?

13. Xob, koj̄ā berym xānūme Faraḥmand?

a. Well, where go we Miss Farahmand?.

b. Well, where do we go Miss Farahmand?

14. Mehmūne man bāšyd.

a. Guest my be.

b. Be my guest.

15. Byā berym byrūn, ye jaāyy benšynym.

a. Come go out, a place sit.

b. Let's go out, (and) sit somewhere.

16. Ye gylāsy bā ham bezanym, bāše?

a. A glass with each other have, ok?

b. Let's have a glass (of drink), ok?

17. Myāy ye do se rūzy berym Tehrān Havāyy Tāze Konym?

a. Do you come two or three days go to Tehran to change the weather?

b. Do you come to Tehran for two or three days to get refreshed?

18. Hālā dyge bāyad sūpemono bokhūrym va berym dyge esterāhat konym.

a. Now should our soup eat and go to take rest.

$b$. Now, that's time to eat our soup and to take a rest then.

19. Xāheš mykonam befarmāyyn tū.

a. Please come in.

b. Come on in, please.

20. Befarmāyyn ye galūyy tāze konyn.

a. Please a throat refresh.

b. Please drink something to get refreshed.

21. čerā sare pā xāheš mykonam befarmāyyd.

a. Why on your feet, please sit down.

$b$. Why are you standing, sit down, please (take a seat, please).

22. Vodkāye Kātryn dar āqūše Kūnyāke Nāpelūn...Berym?

a. Catherin Vodka in the hug of Napoleon cognac...go? 
b. Catherin vodka along with Napoleon cognac.... Drink?

23. Desere b`de šām rā mehmāne man.

a. Dessert after lunch my guest.

b. The dessert of lunch on me.

24. Mytūnam šomāro be šām d'vat konam.

a. Can I you to dinner invite?

b. Can I invite you to dinner?

25. Fardā šab montazeram. Sā‘t dah.

a. Tomorrow night I wait. O'clock ten.

b. I wait for you tomorrow night. At ten o'clock.

26. Emrūz ba'd az ẓohr, Taǰryš. Restūrāne Barg ro balady?

a. Today afternoon, Tajrish. Restaurant Barg do you know?

b. Today afternoon, Tajrish. Do you know Barg Restaurant?

27. myxāhy emšab beravim synamā?

a. Do you want tonight we go to cinema?

b. Do you want to go to the movies tonight?

28. Šanbeye āyandeh be monāsebate xaryde xāne mehmāny dārym, mytavāny byāyy?

a. Saturday next for buying a house party we have. Can you come?

b. I'm giving a house warming party next Saturday. Can you come?

29. myxāhy emrūz ba'd az zohr bā man tenys bāzy kony?

a. Do you want today afternoon with me tennis play?

b. Do you want to play tennis with me this afternoon?

30. Fardā šab mehmūnye kūčaky dārym, mytavāny byāyy?

a. Tomorrow night small party we have, can you come?

b. We are having a small get-together tomorrow night, can you come?

31. Dūst dāry emšab bā man šām boxūry?

a. Do you like tonight with me dinner eat?

b. Would you like to have dinner with me tonight?

32. četowr ast beravym restūrāne eytālyāyye nazdyke daftare tū?

a. How is it to go to restaurant Italian near your office?

b. How about the Italian restaurant near your office?

\section{Formal Verbal English Invitation}

Inviting people to join you for dinner, social events, or other occasions is usually done using "would like" to indicate the invitation. This form can be used for both formal and informal invitations. Remember that "would you like..." is always followed by the infinitive form of the verb (to do).

1. We'd be delighted to have you over for my birthday party.

2. We'd like to invite you and your wife round/over.

-to have you and your wife round/over. 
-you and your wife to join us.

-you and your wife to be our guests.

(Molinsky \& Bliss, 2002, p. 101)

3. How would you like to go to a movie tonight? (Ockenden \& Jones, 1982, p. 66)

4. How would you like to go the zoo this Sunday? (Molinsky \& Bliss, 2002, p. 98)

5. Would you be interested in seeing a film? (Molinsky \& Bliss, 2002, p. 98)

6. Would you like to come with us?

7. Would you like to join us for dinner this evening?

8. Would you like to go to a party tonight? (Ockenden \& Jones, 1982, p. 66)

9. Would you like some coffee? (Dehghan, 1384, p. 2)

10. Would you like to go to a soccer game? (Richards, Hull, \& Proctor, 2005b, p. 109)

11. Would you like to visit an amusement park this weekend? (Richards et al., 2005b, p. 109)

12. Would you like to go to an art festival on Saturday afternoon? (Richards et al., 2005b, p. 109)

13. Would you like to go out on Friday? (Richards, Hull, \& Proctor, 2005a, p. 26)

14. Would you like to come over for dinner tomorrow night? (Richards et al., 2005a, p. 26)

15. Would you like to go to a pop concert with me this weekend? (Richards et al., 2005a, p. 26)

16. If you are not busy, would you be interested in seeing a film with me this Saturday? (Molinsky \& Bliss, 2002, p. 98)

17. If you don't have any other plans, would you be interested in seeing a film with me this Saturday? (Molinsky \& Bliss, 2002, p. 98)

18. If you are free, would you be interested in seeing a film with me this Saturday? (Molinsky \& Bliss, 2002, p. 98)

\section{Informal Verbal English Invitation}

It is also common to use suggestion forms in more informal situations to invite other people to join you in doing something. These forms include "let's do, how about/what about doing, shall we".

19. Let's go to our place for dinner.

20. Let's go roller-skating. (Ockenden \& Jones, 1982, p. 66)

21. Let's see a film. (Molinsky \& Bliss, 2002, p. 98)

22. Are you doing anything on Friday? Do you want to see a movie? (Richards et al., 2005a, p. 26)

23. How about joining us for ice-cream?

24. How about seeing a film? (Molinsky \& Bliss, 2002, p. 98)

25. How about going to see a movie tonight? (Ockenden \& Jones, 1982, p. 66)

26. Well, would you like to do anything? (Ockenden \& Jones, 1982, p. 66)

27. What about trying that new Chinese restaurant? (Ockenden \& Jones, 1982, p. 66)

28. What are you doing tonight? Would you like to go out? (Richards et al., 2005a, p. 101)

29. Why don't you have dinner with me tonight? (Ockenden \& Jones, 1982, p. 66)

30. Why don't we go dancing? (Ockenden \& Jones, 1982, p. 66)

31. Why don't we just go out and get something to eat? (Ockenden \& Jones, 1982, p. 66) 
32. Do you feel like going to see Paul and Claire tonight? (Ockenden \& Jones, 1982, p. 66)

33. Do you want to go to a party with me tonight? (Richards et al., 2005b, p. 109)

34. Do you want to see a movie with me tomorrow night? (Richards et al., 2005b, p. 108)

35. Do you like to go to a basketball game tomorrow night? (Richards et al., 2005b, p. 109)

36. Do you want to go bowling? (Richards et al., 2005a, p. 100)

37. Do you want to go swimming on Saturday? (Richards et al., 2005b, p. 109)

38. I'm organizing a company picnic for this Saturday, Can you come?

-Do you think you'll be able to come?

-Can you make it?

-Do you think you can make it? (Molinsky \& Bliss, 2002, p. 98).

39. I'm on my way to the cafeteria now. Are you free? (Richards et al., 2005a, p. 5).

\section{Formal written English Invitation}

Invitations to formal dinners, luncheons, and other entertainments are sometimes written in the third person. Replies to such invitations should correspond to them in form. Invitations in the third person are less common than formerly; but since they are sometimes used, it is well to recognize them, and to know the proper form of reply. Invitations on the part of an organization, such as a class or a club, are written in the third person.

40. Mrs. George White requests the pleasure of Mr. and Mrs. Lloyd's company at luncheon on Friday, October 12th, at one o'clock, to meet Miss Sanford.

41. Mr. John Black and Mrs. Smith request the honor of your presence at the marriage of their daughter, Mary Black, to Mr. John Brown on Tuesday the first of November at twelve o'clock at John's Church.

\section{Informal Written English Invitation}

42. Hush.... Can you keep a secret? Please join us for a surprise birthday party in honor of Alison Smith. Saturday June 10th. Arrive before 5:00.

\section{Conclusion}

We conclude from the findings of this study that both in English and Persian it is possible to use imperative sentences in informal situations in order to invite others. Another common point which both languages meet is the fact that in inviting others the addressor may use questions, as a polite factor, to give the addressee the opportunity of accepting or rejecting the invitation such as: What are you doing on (day/date)? Would you like to...? How about...? Do you want to... with me?

In Persian we follow the exact time, Present, where as in English we can also use past form of "will" and "can" to refer to present. To sum up, in both English and Persian formal and informal invitations are made by realizing the relationship as well as the situation.

Our results show that the structure of invitations in Persian is more complex than in English. Invitations that meet the criteria for being genuine invitations in English can be classified as ostensible by Persian speakers. In contrast to the claim, regarding English speakers that "ostensible invitations are rare in most situations", our observations show that Persian speakers use a considerable number of ostensible invitations in their daily activities as a manifestation of ritual politeness (ta'arof). 


\section{References}

Ashrafi, A. H. (1346). Engelisi dar safar: Mokaleme Va Estelahate Rozmareye Engelisi (English for travel: Everyday English conversations and terms) (p. 101). Tehran: Estandard.

Dehghan, A. R. (1384). Family album. Tehran: Rahnama.

Eliati, M. (1329). Madmazel Kati (Madame Kathy) (p. 33). Tehran: Cheshme.

Hancher, M. (1979). The classification of co-operative illocutionary acts. Language in Society, 1, 1-14.

Hosseini, M. (1388). Nemitavanam be To Fekr Nakonam Sima (I cannot think of you, Sima) (pp. 22, 25). Tehran: Sales.

Khodaee, A. (1379). Tamame Zemestan Mara Garm Kon (Make me warm all over the winter) (pp. 29, 30, 34, 49). Tehran: Fararang. Lado, R. (1957). Linguistic across culture. Ann Arbor: University of Michigan Press.

Mastor, M. (1382). Man Danaye Kol Hastam (I am The Full-Wise) (pp. 12, 18). Tehran: Ghoghnos.

Molinsky, S. J., \& Bliss, B. (2002). International expressways version 1. New York: Pearson PTR Interactive.

Mortezapour, A. (2009). Rahnamayeh Kamele Namenegari (Comprehensive guide to letter writing). Tehran: Attar.

Ockenden, M., \& Jones, T. (1982). Around town situational conversation practice. New York: Longman Inc..

Radi, A. (1385). Ofol (Decline) (pp. 33, 45, 57). Tehran: Ghatre.

Radi, A. (1387). Dar Meh Bekhan (Sing in the fog) (pp. 14, 42). Tehran: Ghatreh.

Radi, A. (1387). Labkhande Bashokouhe Aghaye Gil (Mr. Gil's magnificent smile) (pp. 31, 83). Tehran: Ghatre.

Radi, A. (2009). Ersyeyeh irani (Iranian heritage). Tehran: Ghatreh.

Richards, J. C., Bycina, D., \& Wisnewska, I. (2005). Person to person: Communicative speaking and listening skills (3rd ed.). New York, NY: Oxford University Press.

Richards, J. C., Hull, J., \& Proctor, S. (2005a). Interchange 1. New York: Cambridge University Press.

Richards, J. C., Hull, J., \& Proctor, S. (2005b). Interchange Intro. New York: Cambridge University Press.

Schmitt, E. E. (1960). Pettis Crimes Conjugaux (Khorde Jenayathaye Zanashoee) (Sh. Haari, Trans.) (p. 66). Tehran: Ghatre.

Searle, J. (1979). Referential and attributive. Monist, 62, 190-208.

Sorkhabi, M. (1385). Estelahat va Mokalemete Engelisi Amrikaee (American English idioms and conversation) (pp. 65-69). Tehran: Rahnama. 